\title{
Air-water exchange of polychlorinated biphenyls (PCBs) and organochlorine pesticides (OCPs) at a coastal site in Izmir Bay, Turkey
}

\author{
Mustafa Odabasi ${ }^{\mathrm{a}, *}$, Banu Cetin ${ }^{\mathrm{a}}$, Eylem Demircioglu ${ }^{\mathrm{a}}$, Aysun Sofuoglu ${ }^{\mathrm{b}}$ \\ a Department of Environmental Engineering, Faculty of Engineering, Dokuz Eylul University, Kaynaklar Campus, 35160 Buca, Izmir, Turkey \\ ${ }^{\mathrm{b}}$ Department of Chemical Engineering, Faculty of Engineering, Izmir Institute of Technology, 35460 Gulbahce-Urla, Izmir, Turkey
}

Received 10 April 2007; received in revised form 22 October 2007

Available online 17 January 2008

\begin{abstract}
The air-water exchange of polychlorinated biphenyl (PCB) and organochlorine pesticides (OCPs) were investigated using paired air-water samples $(n=16)$ collected in July and February-March, 2005 from Guzelyali Port in Izmir Bay, Turkey. Atmospheric PCBs and OCPs were mainly in gas-phase in both periods. However, their dissolved and particle-phase water concentrations were comparable. For $\mathrm{PCBs}, 3$ and 4-Cl congeners were dominant while chlorpyrifos, endosulfans and HCHs were the most abundant OCPs for all samples. Especially in summer, calculated net gas-exchange PCB fluxes were mainly volatilization from the water ranging from -0.2 (volatilization, PCB-101) to -30.0 (volatilization, PCB-31) ng $\mathrm{m}^{-2}$ day $^{-1}$. For OCPs, net flux ranged from -0.03 (volatilization, cis-nonachlor) to 1568 (deposition, endosulfan I) $\mathrm{ng} \mathrm{m}^{-2}$ day $^{-1}$ and they have seasonal variations with generally deposition in winter and volatilization in summer. However, endosulfan I, II, endosulfan sulfate, $\alpha-$ and $\gamma$ $\mathrm{HCH}$ deposited in both periods. The calculated residence times of PCBs and OCPs in the water column indicated that the gasexchange in the Bay is at least as or a more important mechanism than advection. Annual gaseous absorption and volatilization fluxes were calculated and were used along with the estimated dry deposition fluxes and wet deposition fluxes measured recently at a suburban site in Izmir to determine the relative contributions of different atmospheric mechanisms to the pollutant inventory of the Bay water column. Results suggested that the relative contributions of all studied mechanisms to the water column PCB and OCP inventories were significant.
\end{abstract}

(C) 2008 Elsevier B.V. All rights reserved.

Keywords: PCBs; OCPs; Air-water exchange; Fugacity ratio; Henry's law constant

\section{Introduction}

Primary emissions of persistent organic pollutants (POPs) into the atmosphere have changed over the past decades. Polychlorinated biphenyl (PCB) emissions for

\footnotetext{
* Corresponding author. Tel.: +90 232412 7122; fax: +90 2324127280 .

E-mail address: mustafa.odabasi@deu.edu.tr (M. Odabasi).
}

example have declined since 1960s/1970s (Jaward et al., 2004). The use of most of the OCPs was banned/ restricted in Turkey as in many countries because of persistent contamination of the environment. However, some OCPs (chlorpyrifos and endosulfans) are currently used.

The dynamics of air-ocean exchange and processes within the ocean are critical to the global fate and 
behavior of POPs. The capacity of surface waters to store POPs is spatially and temporarily variable, and influenced by the temperature, mixing depth, and biogeochemical processes (Jaward et al., 2004). POPs deposited to surface waters may be further subject to incorporation into the marine food chain, degradation, and eventually deposition into the deep sea. Surface waters may therefore act as "buffers" between the atmosphere and deep-sea (Jaward et al., 2004). The magnitude and direction of air-water exchange has been investigated extensively because of its significant contribution to the cycling of POPs in the environment (Bamford et al., 2002a; Gigliotti et al., 2002; Nelson et al., 1998; Totten et al., 2001). Paired or unpaired air and water concentration measurements in conjunction with the two-film model have been commonly used to estimate atmospheric loadings of POPs to water bodies (Bamford et al., 2002a; Gigliotti et al., 2002; Hoff et al., 1996; Nelson et al., 1998; Totten et al., 2001). In addition to gas-exchange, other mechanisms (particle dry deposition, wet deposition, river/stream outflows, terrestrial run-off, domestic and industrial wastewater discharges) may also significantly contribute to the POP loadings to the water bodies.

Izmir metropolitan city, with a population of 2.7 million is the center of a highly industrialized area by the Aegean Sea shoreline of Turkey. Izmir is densely populated over two narrow flat basins between three series of mountains aligned perpendicular to the seashore. Izmir Bay, one of the great natural bays of the Mediterranean, has been heavily polluted by large amounts of untreated domestic and industrial wastewater discharges (Kucuksezgin et al., 2006). In early 2000, the wastewater treatment plant began to treat $\sim 60 \%$ of domestic and industrial wastewaters and it became fully operative after 2001. However, a recent study reported that the nutrient concentrations were comparably higher in the middle and inner parts of the Bay than those measured in the outer Bay indicating that the water quality in the middle and inner parts of the Bay has not yet been improved significantly (Kucuksezgin et al., 2006). Eutrophication of the inner bay is a serious problem throughout the year and red tide events are becoming more frequent (Kontas et al., 2004). Previous studies on marine pollution of the Bay have been mainly concentrated on nutrients, heavy metals and total hydrocarbons (Kucuksezgin et al., 2006; Kontas et al., 2004). Only recently, the air-water exchange and dry deposition of specific POPs (i.e., polybrominated diphenyl ethers, PBDEs) in the area have been investigated (Cetin and Odabasi, 2007). However, the levels of PCBs and OCPs in the Bay water and in the overlying atmosphere have not been investigated.
The objective of this study was to investigate the magnitude and direction of air-water exchange fluxes of PCBs and OCPs at a coastal site in Izmir Bay, Turkey. Paired air and aqueous concentrations of several PCBs and OCPs were measured during two sampling programs (summer and winter) in 2005. Measured concentrations and meteorological parameters were incorporated into the two-film model to determine the magnitude and direction of air-water exchange fluxes.

\section{Materials and methods}

\subsection{Air and water sampling}

Concurrent surface water and air samples $(n=16)$ were collected during two sampling programs on February 9-March 4 and July 6-13, 2005 from Guzelyali Port. Guzelyali Port is an urban site located at the south of Izmir Bay (Fig. 1). Detailed information on the Izmir Bay can be found elsewhere (Sayin, 2003). Meteorological data (air temperature, wind speed and direction, and relative humidity) was taken from Guzelyali station located $\sim 500 \mathrm{~m}$ from the sampling site while surface water temperatures were measured onsite. Average water temperatures were $10.1 \pm 0.8^{\circ} \mathrm{C}$ and $27.0 \pm 0.8^{\circ} \mathrm{C}$ for winter and summer sampling periods, respectively while the air temperatures measured during the same periods were $9.7 \pm 4.0^{\circ} \mathrm{C}$ and $31.8 \pm 1.5{ }^{\circ} \mathrm{C}$. Wind speed ranged between 2.4 and 5.2 and between 2.7 and $5.2 \mathrm{~m} \mathrm{~s}^{-1}$ during the winter and summer sampling periods, respectively. Long-term observations indicate that the prevailing wind direction in the area is NW. During the sampling programs generally northerly winds prevailed (except for two days of winter sampling) indicating that the sampled air was off the Bay water but also affected by the urban plume from the densely populated areas around the Izmir Bay (Fig. 1).

Water samples $(\sim 55 \mathrm{~L})$ were collected at the beginning of each air sampling (at 9.00 a.m.) manually from 30 -cm depth using high-density polyethylene containers without leaving a headspace.

Air samples were collected using a modified highvolume sampler (Model GPS-11, Thermo-Andersen Inc.). Particles were collected on $10.5-\mathrm{cm}$ diameter quartz filters and the gas-phase compounds were collected in a cartridge containing polyurethane foam (PUF) $(6-\mathrm{cm}$ diameter, 10-cm length). The average sampling volume was $89 \pm 16 \mathrm{~m}^{3}$ and the sampling duration was $6.4 \pm 1.2 \mathrm{~h}$.

Prior to sampling, quartz filters were baked at $450{ }^{\circ} \mathrm{C}$ overnight. Then, they were allowed to cool to room temperature in a desiccator. PUF cartridges were cleaned by Soxhlet extraction using acetone:hexane 


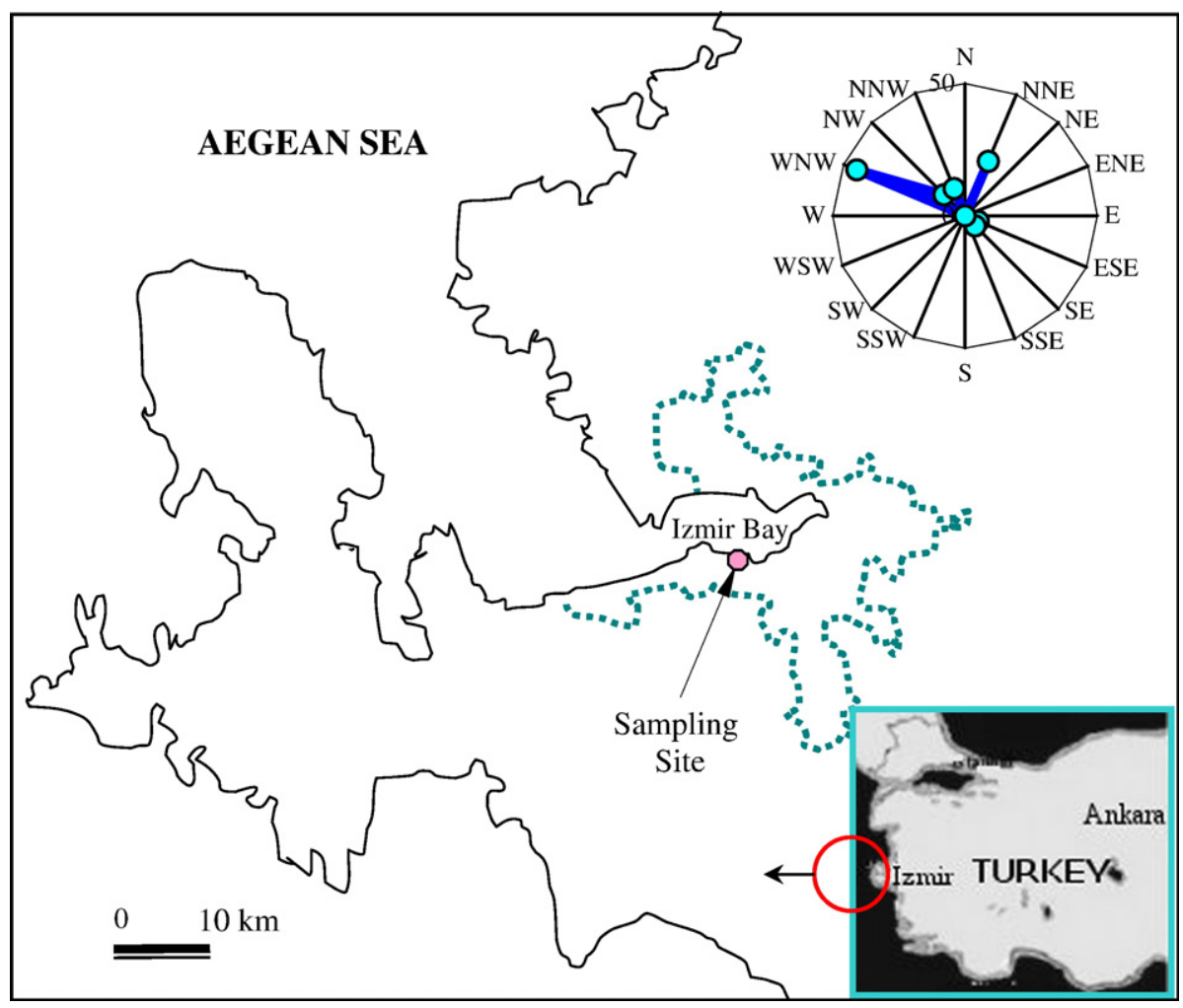

Fig. 1. Map of Izmir Bay showing the sampling site. Dotted line shows the densely populated sites. Wind rose shows the frequency (\%) of prevailing wind directions during the sampling programs.

mixture (1:1) for $24 \mathrm{~h}$, were dried in an oven at $70{ }^{\circ} \mathrm{C}$, and were stored in glass jars capped with Teflon-lined lids. After sampling, PS-1 filters and PUF cartridges were stored at $-20{ }^{\circ} \mathrm{C}$ in their containers.

\subsection{Sample preparation and analysis}

Water samples were filtered through a glass fiber filter $(47-\mathrm{mm}$ diameter, $0.7 \mu \mathrm{m}$ pore size) to collect particle-phase in series with a resin column $(\sim 10 \mathrm{~g}$ XAD-2) to collect dissolved-phase PCBs and OCPs. Water samples were processed within $2 \mathrm{~h}$ after collection. Four different samples were obtained in each sampling day (i.e., PUF cartridge, air filter, resin and water filter). PUF cartridges were Soxhlet extracted for $24 \mathrm{~h}$, and quartz filters, resin and water filters were ultrasonically extracted for $60 \mathrm{~min}$ with a mixture of $1: 1$ acetone:hexane. Prior to extraction, all samples were spiked with PCB surrogate standard mixture (PCB-14, 65 , and 166), to monitor the analytical recovery efficiency. The volume of extracts was reduced and transferred into hexane using a rotary evaporator and a high-purity $\mathrm{N}_{2}$ stream. After concentration to $2 \mathrm{~mL}$, sodium sulfate was added to samples to remove residual water and samples were cleaned up and fractionated on an alumina-silicic acid column containing $3 \mathrm{~g}$ silicic acid (deactivated with $4.5 \%$ deionized water) and $2 \mathrm{~g}$ alumina (deactivated with $6 \%$ DI water). The column was pre-washed with $20 \mathrm{~mL}$ dichloromethane (DCM) followed by $20 \mathrm{~mL}$ petroleum ether (PE). Then, the sample in $2 \mathrm{~mL}$ hexane was added to the column and PCBs were eluted with $35 \mathrm{~mL}$ PE (fraction 1) and OCPs were eluted with $25 \mathrm{~mL}$ DCM (fraction 2). The final extracts were solvent exchanged into hexane and were concentrated to $1 \mathrm{~mL}$ under a stream of $\mathrm{N}_{2}$.

Samples were analyzed for PCBs with an Agilent $6890 \mathrm{~N}$ gas chromatograph (GC) equipped with a mass selective detector (Agilent 5973 inert MSD) working at electron impact ionization mode. A capillary column (HP-5 ms, $30 \mathrm{~m}, 0.25 \mathrm{~mm}, 0.25 \mu \mathrm{m}$ ) was used. The initial oven temperature was held at $70^{\circ} \mathrm{C}$ for $2 \mathrm{~min}$, was raised to $150{ }^{\circ} \mathrm{C}$ at $25{ }^{\circ} \mathrm{C} \mathrm{min}{ }^{-1}$, to $200{ }^{\circ} \mathrm{C}$ at $3{ }^{\circ} \mathrm{C}$ $\min ^{-1}$, and to $280{ }^{\circ} \mathrm{C}$ at $8{ }^{\circ} \mathrm{C} \mathrm{min}{ }^{-1}$, and was held for $10 \mathrm{~min}$. The injector, ion source, and quadrupole temperatures were 250,230 , and $150{ }^{\circ} \mathrm{C}$, respectively. The MSD was run in selected ion-monitoring mode.

Prior to analysis OCP samples were spiked with internal standard (BDE-77, 3,3',4,4'-tetrabromodiphenyl 
ether) and they were analyzed with the same capillary column and GC-MS system used for PCB analysis. OCPs were analyzed at electron capture negative chemical ionization (ECNI) mode. The carrier gas (helium) was used at constant flow mode $\left(1.0 \mathrm{~mL} \mathrm{~min}^{-1}\right)$ with a linear velocity of $36 \mathrm{~cm} \mathrm{~s}^{-1}$. The initial oven temperature was held at $50{ }^{\circ} \mathrm{C}$ for $1 \mathrm{~min}$, was raised to $100{ }^{\circ} \mathrm{C}$ at $25^{\circ} \mathrm{C}$ $\min ^{-1}$, to $260^{\circ} \mathrm{C}$ at $5^{\circ} \mathrm{C} \min ^{-1}$, to $300^{\circ} \mathrm{C}$ at $10^{\circ} \mathrm{C} \mathrm{min}^{-1}$, and was held for $2 \mathrm{~min}$. The injector, ion source, and quadrupole temperatures were 250,150 , and $150{ }^{\circ} \mathrm{C}$, respectively. High-purity methane was the reagent gas. The MSD was run in selected ion monitoring mode. Compounds were identified on the basis of their retention times, target and qualifier ions, and were quantified using the internal standard calibration procedure.

\subsection{Quality control}

All samples were spiked with surrogate standards prior to extraction in order to monitor analytical recovery efficiencies. Recoveries of PCB surrogate standards for ambient air samples (filters and PUFs) were $97 \pm 17 \%$ for PCB-14, $107 \pm 18 \%$ for PCB-65, and $93 \pm 31 \%$ for PCB-166 $(n=46)$. Surrogate recoveries for water samples were $79 \pm 20 \%, 92 \pm 20 \%$ and $75 \pm 35 \%$, respectively. The recoveries of target compounds were also tested externally $(n=12)$ and average recovery efficiencies ranged between $69 \pm 15 \%$ (PCB-18) and $115 \pm 5 \%$ (PCB-49) and they were generally $>85 \%$. Procedural recoveries of OCPs were also determined externally $(n=6)$ and they were generally $>70 \%$ (overall average \pm $\mathrm{SD}, 85 \pm 21 \%$ ). Since the recoveries were generally high, sample amounts were not corrected.

Instrumental detection limits (IDL) were determined from linear extrapolation from the lowest standard in calibration curve using the area of a peak having a signal/noise ratio of 3 . The quantifiable PCB amounts were $\sim 0.1 \mathrm{pg}$ while OCP amounts ranged between 0.02 (cis-nonachlor)-0.35 pg (p, $\mathrm{p}^{\prime}$-DDT) for $1 \mu 1$ injection. Blank PUF cartridges and air filters were routinely placed in the field to determine if there was any contamination during sample handling and preparation. PCB blank amounts for PUFs, PS-1 filters, resin and water filters were $8 \pm 13 \%, 30 \pm 21 \%, 18 \pm 19 \%$, and $9 \pm$ $12 \%$ of the sample amounts, respectively. OCP blank amounts for PUFs, PS-1 filters, resin and water filters were $13 \pm 14 \%, 17 \pm 17 \%, 16 \pm 17 \%$, and $15 \pm 16 \%$ of the sample amounts, respectively. The limit of detection of the method (LOD, ng) was defined as the mean blank mass plus three standard deviations ( $\mathrm{LOD}=$ Mean blank value $+3 \mathrm{SD}$ ). Instrumental detection limit was used for the compounds that were not detected in blanks. LODs for PCBs ranged from 0.1 to $1.2 \mathrm{ng}$ for PUFs, 0.1 to $0.6 \mathrm{ng}$ for PS-1 filters, 0.1 to 1.1 for resin, and 0.1 to $0.4 \mathrm{ng}$ for water filters. LODs for OCPs ranged from 0.02 to $10.5 \mathrm{ng}$ for PUFs, 0.02 to $3.3 \mathrm{ng}$ for PS-1 filters, 0.02 to 2.5 for resin, and 0.02 to $2.2 \mathrm{ng}$ for water filters. Sample quantities exceeding the LOD were quantified and blank-corrected by subtracting the mean blank amount from the sample amount.

To check if the analyzed compounds were sorbed to the walls of the aqueous sample containers, they were extracted with $100 \mathrm{~mL}$ mixture of 1:1 acetone:hexane, were processed and analyzed as samples. For all compounds, the amounts were below LOD indicating that wall sorption loss was not significant.

\subsection{Air-water exchange modeling}

According to the Whitman two-film model, mass transfer is limited by the rate of molecular diffusion through thin films of air and water on either side of the surface (Schwarzenbach et al., 2003). The gas flux across a water surface is a function of Henry's law constant, the concentration gradient, and the overall mass transfer coefficient (Hoff et al., 1996; Schwarzenbach et al., 2003). The net diffusive gas-exchange flux $\left(F_{\mathrm{g}}, \mathrm{ng} \mathrm{m}^{-2}\right.$ day $\left.^{-1}\right)$ is driven by the fugacity difference between air and surface water:

$F_{g}=K_{a}\left(C_{a}-C_{w} H / R T\right)$

where $C_{\mathrm{w}}$ and $C_{\mathrm{a}}$ are the water and air concentrations (ng $\left.\mathrm{m}^{-3}\right), H$ is the Henry's law constant $\left(\mathrm{Pa} \mathrm{m}^{-3} \mathrm{~mol}^{-1}\right), R$ is the universal gas constant $\left(8.314 \mathrm{~Pa} \mathrm{~m}^{3} \mathrm{~mol}^{-1} \mathrm{~K}^{-1}\right), K_{\mathrm{a}}$ is the gas-phase overall mass transfer coefficient, and $T$ is temperature at the air-water interface $(\mathrm{K})$.

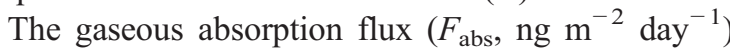
quantifies movement of compounds from air into the water column:

$F_{a b s}=K_{a} C_{a}$

The gaseous volatilization flux $\left(F_{\mathrm{vol}}, \mathrm{ng} \mathrm{m}^{-2}\right.$ day $\left.^{-1}\right)$ quantifies transfer of compounds from the water column into the air:

$F_{\mathrm{vol}}=K_{a} C_{w} H / R T$

$K_{a}$ is related to individual mass transfer coefficients for the liquid and gas films, $k_{\mathrm{w}}$ and $k_{\mathrm{a}}$, as follows:

$1 / K_{a}=\left(1 / k_{a}\right)+\left(H / R T k_{w}\right)$

Mass transfer coefficients of water vapor, oxygen $\left(\mathrm{O}_{2}\right)$ and carbon dioxide $\left(\mathrm{CO}_{2}\right)$ have been related to 
wind speed by many researchers. The following equations can be used to estimate $k_{\mathrm{a}}$ and $k_{\mathrm{w}}$ for organic compounds ( $\mathrm{cm} \mathrm{s}^{-1}$ ) (Nightingale et al., 2000; Schwarzenbach et al., 2003):

$$
\begin{aligned}
& k_{a \text { (compound) }}\left(\mathrm{cm} \mathrm{s}^{-1}\right) \\
& =\left(0.2 U_{10}+0.3\right)\left[D_{a(\text { compound })} / D_{a(\mathrm{H} 2 \mathrm{O})}\right]^{0.67} \\
& k_{w \text { (compound) }}\left(\mathrm{cm} \mathrm{s}^{-1}\right) \\
& =\left[\left(0.24 U_{10}^{2}+0.061 U_{10}\right) / 3600\right] \\
& \times\left[D_{w \text { (compound })} / D_{w(\mathrm{CO} 2)}\right]^{0.5}
\end{aligned}
$$

where $D_{\mathrm{a}}$ and $D_{\mathrm{w}}\left(\mathrm{cm}^{2} \mathrm{~s}^{-1}\right)$ are the diffusivities in air and water, respectively, and $U_{10}$ is the wind speed $10 \mathrm{~m}$ above the water surface $\left(\mathrm{m} \mathrm{s}^{-1}\right)$.

\section{Results and discussion}

\subsection{Water concentrations}

Total dissolved-phase PCB concentrations $\left(\sum_{29} \mathrm{PCBs}\right)$ were $205 \pm 88$ and $132 \pm 31 \mathrm{pg} \mathrm{L}^{-1}$ (average $\pm \mathrm{SD}$ ) for summer and winter seasons, respectively and they were $181 \pm 63$ and $118 \pm 33 \mathrm{pg} \mathrm{L}^{-1}$ for particle-phase (Table 1). Low molecular weight congeners were dominant with homologues 3-5 contributing an average of $85 \%$ to the $\sum_{29} \mathrm{PCB}$ concentrations. However, homologue groups 8 , 9 and PCB-209 were not detected. Average summer $\sum_{29} \mathrm{PCB}$ concentrations were higher than winter concentrations for both dissolved and particulate-phases (twotailed $t$-test, $p<0.05$ ) (Table 1). The PCB concentrations measured in this study were within the range of previously reported concentrations for different surface waters. In a study conducted by Sundqvist et al. (2004), only 8 PCB congeners were investigated and comparably low total (dissolved + particle) concentrations were reported between 1.9 (PCB-52) and $6.8 \mathrm{pg} \mathrm{L}^{-1}$ (PCB-153). Bamford et al. (2002a,b) have reported total dissolved-phase $\mathrm{PCB}$ concentrations as 500 and $430 \mathrm{pg} \mathrm{L}^{-1}$ for Baltimore Harbor and Chesapeake Bay, respectively. In New York-New Jersey Harbor, higher dissolved-phase PCB concentrations were measured with a maximum value of $4160 \mathrm{pg} \mathrm{L}^{-1}$ (Totten et al., 2001). In Delaware River, the highest value of dissolved and particle phase PCB concentrations were 1700 and $4900 \mathrm{pg} \mathrm{L}^{-1}$, respectively (Rowe et al., 2007).

Average dissolved-phase individual organochlorine pesticide concentrations ranged from $0.4 \pm 0.4$ (cis-nonachlor) to $86 \pm 38 \mathrm{pg} \mathrm{L}^{-1}$ (chlorpyrifos) for winter and ranged from $0.8 \pm 0.3$ (trans-nonachlor) to $593 \pm 452 \mathrm{pg}$
$\mathrm{L}^{-1}$ (chlorpyrifos) for summer periods. For particle-phase OCPs, concentrations ranged from $0.2 \pm 0.1$ (cis-nonachlor) to $31 \pm 19 \mathrm{pg} \mathrm{L}^{-1}$ (chlorpyrifos) and from 0.2 (transnonachlor) to $400 \pm 416 \mathrm{pg} \mathrm{L}^{-1}$ (chlorpyrifos) for winter and summer periods, respectively (Table 1). Chlorpyrifos, a current-use pesticide had the highest average concentration. Aqueous chlorpyrifos concentrations increased approximately an order of magnitude from winter to summer, far greater than any other compound (Table 1). This may be due to run-off from agricultural areas associated with fresh pesticide use. Further tentative evidence for terrestrial runoff as a source is the observed high particle-bound currentuse pesticide concentrations (endosulfan, endosulfan sulfate, and particularly chlorpyrifos) during the summer period.

The concentrations observed in the present study were within the ranges previously measured at different sites. In Chesapeake Bay, chlorpyrifos concentrations were between 45 and $1670 \mathrm{pg} \mathrm{L}^{-1}$ (McConnell et al., 1997). Kattegat Sea region was more contaminated by $\mathrm{HCHs}$ with average $\alpha$ and $\gamma$-HCH concentrations of 59 and $630 \mathrm{pg} \mathrm{L}^{-1}$, respectively (Sundqvist et al., 2004). Pearl River and Macao Harbor were also heavily contaminated with OCPs and water column was dominated by $\mathrm{HCHs}$ and DDTs ranging from 8700 to $59600 \mathrm{pg} \mathrm{L}^{-1}$ and from 160 to $29700 \mathrm{pg} \mathrm{L}^{-1}$, respectively (Luo et al., 2004).

\subsection{Ambient air concentrations}

Average gas phase $\Sigma_{29} \mathrm{PCB}$ concentrations were $1642 \pm 817$ and $2078 \pm 1026 \mathrm{pg} \mathrm{m}^{-3}$ for winter and summer periods, respectively and they were $74 \pm 75$ and $41 \pm 40 \mathrm{pg} \mathrm{m}^{-3}$ for particle phase PCBs (Table 1). The average gas-phase concentration was up to $98 \%$ of the total PCB (gas + particle) concentration. This result agrees well with the previously reported values (Sweet et al., 1993; Lee et al., 1996; Simcik et al., 1997; Halsall et al., 1999; Green et al., 2000; Miller et al., 2001; Tasdemir et al., 2005). In a homolog basis, tri-to heptachlorinated homologs were observed in gas-phase samples and their dominance decreased with the increasing halogen number in both periods. However, only tri- and tetra-CBs were dominant in particle phase samples.

The PCB concentrations measured in this study were similar to those reported previously for other urban areas. Similar gas-phase $\Sigma$ PCB concentrations have been reported for the urban area of Integrated Atmospheric Deposition network (IADN) station, Chicago, as $1800 \pm 170 \mathrm{pg} \mathrm{m}^{-3}$ (Buehler et al., 2001). Tasdemir et al. (2005) have reported that the average $\Sigma$ PCB concentration in Chicago was $1900 \pm 1700 \mathrm{pg} \mathrm{m}^{-3}$. Gas-phase $\Sigma$ PCB concentrations were reported as $1180 \pm 420$ pg 
Table 1

Concentrations of PCBs and OCPs in Water and Air (average \pm SD)

\begin{tabular}{|c|c|c|c|c|c|c|c|c|}
\hline & \multicolumn{4}{|c|}{ Water concentrations $\left(\mathrm{pg} \mathrm{L}^{-1}\right)$} & \multicolumn{4}{|c|}{ Air concentrations $\left(\mathrm{pg} \mathrm{m}^{-3}\right)$} \\
\hline & \multicolumn{2}{|c|}{ Dissolved-phase } & \multicolumn{2}{|c|}{ Particle-phase } & \multicolumn{2}{|l|}{ Gas-phase } & \multicolumn{2}{|c|}{ Particle-phase } \\
\hline & Winter & Summer & Winter & Summer & Winter & Summer & Winter & Summer \\
\hline \multicolumn{9}{|l|}{$P C B s$} \\
\hline PCB 18 & $24 \pm 8$ & $22 \pm 12$ & $18 \pm 10$ & $25 \pm 15$ & $129 \pm 62$ & $286 \pm 142$ & $11 \pm 4$ & $8 \pm 7$ \\
\hline PCB 17 & $10 \pm 4$ & $8 \pm 5$ & $8 \pm 4$ & $8 \pm 6$ & $103 \pm 58$ & $135 \pm 60$ & $8 \pm 2$ & $5 \pm 4$ \\
\hline PCB 31 & $7 \pm 4$ & $20 \pm 30$ & $6 \pm 3$ & $19 \pm 9$ & $205 \pm 97$ & $221 \pm 105$ & $6 \pm 5$ & $4 \pm 3$ \\
\hline PCB 28 & $8 \pm 4$ & $17 \pm 13$ & $8 \pm 3$ & $18 \pm 10$ & $173 \pm 97$ & $210 \pm 108$ & $8 \pm 6$ & $5 \pm 5$ \\
\hline PCB 33 & $12 \pm 5$ & $14 \pm 11$ & $6 \pm 2$ & $4 \pm 3$ & $453 \pm 246$ & $212 \pm 98$ & $10 \pm 7$ & $5 \pm 4$ \\
\hline PCB 52 & $8 \pm 3$ & $11 \pm 5$ & $6 \pm 2$ & $10 \pm 3$ & $132 \pm 61$ & $169 \pm 70$ & $12 \pm 20$ & $5 \pm 6$ \\
\hline PCB 49 & $16 \pm 5$ & $21 \pm 13$ & $5 \pm 2$ & $16 \pm 10$ & $125 \pm 65$ & $134 \pm 52$ & $16 \pm 20$ & $6 \pm 6$ \\
\hline PCB 44 & $2 \pm 3$ & 0.7 & $\mathrm{Nd}$ & $\mathrm{Nd}$ & $92 \pm 45$ & $118 \pm 62$ & $\mathrm{Nd}$ & $\mathrm{Nd}$ \\
\hline РCB 74 & 0.7 & 0.7 & $\mathrm{Nd}$ & $\mathrm{Nd}$ & $47 \pm 5$ & $59 \pm 27$ & $\mathrm{Nd}$ & $\mathrm{Nd}$ \\
\hline PCB 70 & $6 \pm 4$ & $16 \pm 5$ & 28 & $\mathrm{Nd}$ & $64 \pm 34$ & $86 \pm 51$ & $\mathrm{Nd}$ & $\mathrm{Nd}$ \\
\hline PCB 95 & $2 \pm 0.7$ & $5 \pm 2$ & $3 \pm 0.7$ & $6 \pm 1.4$ & $27 \pm 17$ & $61 \pm 34$ & $\mathrm{Nd}$ & 2 \\
\hline PCB 101 & $2 \pm 1.2$ & $6 \pm 3$ & $5 \pm 0.9$ & $10 \pm 4$ & $21 \pm 16$ & $60 \pm 36$ & $3 \pm 0.1$ & $3 \pm 3$ \\
\hline РCB 99 & 2 & $3 \pm 1.1$ & $3 \pm 0.8$ & $4 \pm 0.9$ & $11 \pm 7$ & $29 \pm 18$ & $\mathrm{Nd}$ & $\mathrm{Nd}$ \\
\hline PCB 87 & $3 \pm 1.1$ & $7 \pm 2$ & $4 \pm 2$ & $7 \pm 2$ & $12 \pm 11$ & $34 \pm 19$ & $\mathrm{Nd}$ & $\mathrm{Nd}$ \\
\hline PCB 110 & $4 \pm 2$ & $8 \pm 2$ & $5 \pm 1.2$ & $7 \pm 3$ & $19 \pm 12$ & $57 \pm 34$ & $\mathrm{Nd}$ & $2 \pm 0.4$ \\
\hline PCB 82 & $8 \pm 4$ & $9 \pm 5$ & $5 \pm 2$ & $7 \pm 3$ & $0.8 \pm 0$ & $13 \pm 9$ & $\mathrm{Nd}$ & $\mathrm{Nd}$ \\
\hline PCB 151 & $1.3 \pm 0.6$ & $2 \pm 1.2$ & $2 \pm 0.8$ & $2 \pm 0.8$ & $6 \pm 2$ & $9 \pm 5$ & $\mathrm{Nd}$ & 2 \\
\hline PCB 149 & $2 \pm 0.9$ & $5 \pm 2$ & $6 \pm 2$ & $8 \pm 2$ & $10 \pm 6$ & $31 \pm 18$ & $\mathrm{Nd}$ & $2 \pm 0.9$ \\
\hline PCB 118 & $6 \pm 2$ & $12 \pm 3$ & $9 \pm 3$ & $13 \pm 4$ & $13 \pm 8$ & $41 \pm 24$ & $\mathrm{Nd}$ & 3 \\
\hline РCB 153 & $3 \pm 1.2$ & $4 \pm 1.2$ & $5 \pm 2$ & $7 \pm 1.1$ & $9 \pm 5$ & $31 \pm 18$ & $18 \pm 21$ & $2 \pm 1.1$ \\
\hline PCB 132 & $1.4 \pm 0.8$ & $2 \pm 1.1$ & $1.8 \pm 0.3$ & $3 \pm 0.3$ & $6 \pm 4$ & $14 \pm 8$ & $\mathrm{Nd}$ & $\mathrm{Nd}$ \\
\hline PCB 105 & 0.7 & $1.4 \pm 1.3$ & 2.6 & $\mathrm{Nd}$ & $9 \pm 3$ & $16 \pm 9$ & $\mathrm{Nd}$ & $\mathrm{Nd}$ \\
\hline РCB 138 & $3 \pm 2$ & $3 \pm 2$ & $5.4 \pm 1.6$ & $7 \pm 3$ & $11 \pm 9$ & $39 \pm 23$ & 4 & $\mathrm{Nd}$ \\
\hline PCB 158 & $\mathrm{Nd}$ & 0.7 & $\mathrm{Nd}$ & $\mathrm{Nd}$ & $\mathrm{Nd}$ & $8 \pm 3$ & $\mathrm{Nd}$ & $\mathrm{Nd}$ \\
\hline PCB 187 & $2 \pm 0.9$ & $1.3 \pm 0.6$ & $2.7 \pm 0.8$ & $2 \pm 0.5$ & $5 \pm 4$ & $6 \pm 2$ & 7 & $\mathrm{Nd}$ \\
\hline РCB 183 & $2 \pm 0.3$ & $1.0 \pm 0.7$ & $2 \pm 0.9$ & $1.1 \pm 0.4$ & 0.8 & $4 \pm 2$ & $\mathrm{Nd}$ & $\mathrm{Nd}$ \\
\hline PCB 128 & $\mathrm{Nd}$ & 0.7 & $\mathrm{Nd}$ & $\mathrm{Nd}$ & $\mathrm{Nd}$ & $11 \pm 6$ & $\mathrm{Nd}$ & $\mathrm{Nd}$ \\
\hline PCB 177 & $\mathrm{Nd}$ & 0.7 & $\mathrm{Nd}$ & $\mathrm{Nd}$ & $\mathrm{Nd}$ & $5 \pm 1$ & 1 & $\mathrm{Nd}$ \\
\hline PCB 180 & $4 \pm 0.5$ & $3 \pm 2$ & $4 \pm 1.2$ & $3 \pm 1.1$ & 0.8 & $9 \pm 3$ & $\mathrm{Nd}$ & $\mathrm{Nd}$ \\
\hline$\Sigma_{29} \mathrm{PCBs}$ & $132 \pm 31$ & $205 \pm 88$ & $118 \pm 33$ & $181 \pm 63$ & $1642 \pm 817$ & $2078 \pm 1026$ & $74 \pm 75$ & $41 \pm 40$ \\
\hline \multicolumn{9}{|l|}{ OCPs } \\
\hline$\alpha-\mathrm{HCH}$ & $17 \pm 4$ & $32 \pm 6$ & $3 \pm 2$ & $2 \pm 0.7$ & $43 \pm 22$ & $62 \pm 19$ & $1.4 \pm 0.5$ & $0.8 \pm 0.4$ \\
\hline$\gamma-\mathrm{HCH}$ & $15 \pm 3$ & $29 \pm 6$ & $3 \pm 2$ & $7 \pm 2$ & $88 \pm 53$ & $28 \pm 8$ & $3 \pm 1.1$ & $2 \pm 1.3$ \\
\hline CHLPYR & $86 \pm 38$ & $593 \pm 452$ & $31 \pm 19$ & $400 \pm 416$ & $1154 \pm 502$ & $864 \pm 255$ & $10 \pm 5$ & $157 \pm 115$ \\
\hline HEP EPOX & $5 \pm 4$ & $22 \pm 8$ & $11 \pm 4$ & $4 \pm 2$ & $91 \pm 147$ & $9 \pm 3$ & $5 \pm 4$ & $1 \pm 0.3$ \\
\hline$\gamma$-CHL & $0.6 \pm 0.3$ & $4 \pm 2$ & $0.5 \pm 0.3$ & $0.4 \pm 0.1$ & $9 \pm 4$ & $0.8 \pm 0.3$ & $0.2 \pm 0.2$ & $0.2 \pm 0$ \\
\hline ESLF I & $6 \pm 3$ & $19 \pm 10$ & $4 \pm 2$ & $10 \pm 6$ & $80 \pm 26$ & $4474 \pm 1937$ & $4 \pm 3$ & $13 \pm 8$ \\
\hline$\alpha-\mathrm{CHL}$ & $0.7 \pm 0.5$ & $1.5 \pm 0.7$ & $0.4 \pm 0.3$ & $0.3 \pm 0.2$ & $6 \pm 3$ & $2 \pm 0.6$ & $0.3 \pm 0.2$ & $0.2 \pm 0.3$ \\
\hline t-NONA & $0.7 \pm 0.5$ & $0.8 \pm 0.3$ & $0.4 \pm 0.3$ & 0.2 & $1.4 \pm 1$ & $0.2 \pm 0.1$ & $0.3 \pm 0.1$ & $0.1 \pm 0.1$ \\
\hline ESLF II & $4 \pm 1.3$ & $9 \pm 2$ & $1.5 \pm 0.5$ & $3 \pm 0.8$ & $11 \pm 4$ & $879 \pm 464$ & $2 \pm 0.9$ & $77 \pm 47$ \\
\hline c-NONA & $0.4 \pm 0.4$ & $2 \pm 0.6$ & $0.2 \pm 0.1$ & $0.3 \pm 0.1$ & $0.2 \pm 0.3$ & $0.4 \pm 0.2$ & $0.1 \pm 0.1$ & $0.1 \pm 0.1$ \\
\hline ESULFATE & $17 \pm 8$ & $71 \pm 25$ & $2.3 \pm 2.4$ & $3.8 \pm 0.7$ & $3 \pm 1.4$ & $28 \pm 19$ & $1.1 \pm 0.7$ & $22 \pm 11$ \\
\hline $\mathrm{p}, \mathrm{p}^{\prime}-\mathrm{DDT}$ & $10 \pm 3$ & $13 \pm 12$ & $10 \pm 4$ & $6 \pm 3$ & $8 \pm 8$ & $5 \pm 2$ & $2 \pm 0.9$ & $2 \pm 0.8$ \\
\hline
\end{tabular}

$\alpha, \gamma$-Hexachlorocyclohexane isomers $(\alpha, \gamma$-HCH), chlorpyrifos (CHLPYR), heptachlor epoxide (HEP EPOX), endosulfan I (ESLF I), endosulfan II (ESLF II), endosulfan sulfate (ESULFATE), $\alpha$-chlordane ( $\alpha$-CHL), $\gamma$-chlordane $(\gamma$-CHL), trans-nonachlor (t-NONA), cis-nonachlor (c-NONA), $\mathrm{p}, \mathrm{p}^{\prime}$-dichlorodiphenyltrichloroethane ( $\mathrm{p}, \mathrm{p}^{\prime}$-DDT).

Nd: not detected.

$\mathrm{m}^{-3}$ at Baltimore and $550 \pm 220 \mathrm{pg} \mathrm{m}^{-3}$ at the Chesapeake Bay (Brunciak et al., 2001).

Average gas-phase individual OCP concentrations ranged from $0.2 \pm 0.3$ (cis-nonachlor) to $1154 \pm 502 \mathrm{pg}$ $\mathrm{m}^{-3}$ (chlorpyrifos) for winter and from $0.2 \pm 0.1$ (transnonachlor) to $4474 \pm 1937 \mathrm{pg} \mathrm{m}^{-3}$ (endosulfan I) for summer. For particle-phase OCPs, they ranged from $0.1 \pm$ 0.1 (cis-nonachlor) to $10 \pm 5 \mathrm{pg} \mathrm{m}^{-3}$ (chlorpyrifos) and 
$0.1 \pm 0.1$ (cis-nonachlor) to $157 \pm 115 \mathrm{pg} \mathrm{m}^{-3}$ (chlorpyrifos), respectively (Table 1). Chlorpyrifos and endosulfan I and II, currently used pesticides, had relatively higher concentrations among the OCPs and they were followed by $\alpha-, \gamma-\mathrm{HCHs}$, and endosulfan sulfate (a degradation product of endolsulfan) (Table 1). The average ratio of $\alpha$ $\mathrm{HCH}$ to $\gamma-\mathrm{HCH}$ was $1.1 \pm 0.3$ for all ambient air samples. It was reported that $\alpha-\mathrm{HCH} / \gamma-\mathrm{HCH}$ ratios were close to 1 in areas where lindane $(\gamma-\mathrm{HCH})$ was used, and between 3-7 in remote areas or where technical $\mathrm{HCH}$ was used (Lee et al., 2000; Murayama et al., 2003). The use of technical $\mathrm{HCH}$ and lindane has been prohibited for more than 20 years in Turkey. However, lindane has been used in Europe until recently (Lee et al., 2000). A recent study conducted using passive samplers at a continental scale reported that $\alpha-\mathrm{HCH} / \gamma-\mathrm{HCH}$ ratios were generally $<1$ in neighboring countries (Greece and Cyprus) and over the Europe (Jaward et al., 2004). Therefore, the relatively low $\alpha-\mathrm{HCH} / \gamma-\mathrm{HCH}$ ratios observed in this study can be attributed to the effect of regional sources.

In a study conducted at a suburban site of Izmir, Turkey, relatively low average OCP concentrations were reported ranging from $5 \pm 4 \mathrm{pg} \mathrm{m}^{-3}$ (p, $\mathrm{p}^{\prime}$-DDD) to $391 \pm 306 \mathrm{pg} \mathrm{m}^{-3}$ (chlorpyrifos) (Sofuoglu et al., 2004). In U.K., mean concentrations of the pesticides were between $8\left(\mathrm{p}, \mathrm{p}^{\prime}\right.$-DDE) and $500(\gamma-\mathrm{HCH}) \mathrm{pg} \mathrm{m}^{-3}$ (Lee et al., 2000). In Chesapeake Bay, gas phase concentrations of chlorpyrifos were found between 2 and $97 \mathrm{pg}$ $\mathrm{m}^{-3}$ (McConnell et al., 1997), lower than those measured in the present study. However, Arizona was more contaminated with chlorpyrifos and its concentration ranged between 4100 and $22500 \mathrm{pg} \mathrm{m}^{-3}$ (Moschandreas et al., 2001).

\subsection{Air-water exchange}

Concurrent air and water concentrations are ideally used to assess the state of equilibrium for individual POPs between the air-water interfaces. The water-air fugacity ratio $\left(f_{\mathrm{W}} / f_{\mathrm{A}}=H^{\prime} C_{\mathrm{w}} / C_{\mathrm{a}}\right)>1.0$ indicates net volatilization of compounds from water, values $<1.0$ indicate net gas-phase deposition from air. For a system in equilibrium, $f_{\mathrm{W}} / f_{\mathrm{A}}$ value is $\sim 1.0$.

$H$ is an important parameter that plays a fundamental role in predicting the transport, behavior and fate of POPs in the environment and it is required to model gasexchange in aquatic systems. Therefore, it is crucial to know the $H$ of POPs as precisely and accurately as possible. $H$ values for PCBs have been reported by several studies ( $\mathrm{Li}$ et al., 2003). The studies by Bamford et al. (2002b, 2000) which measured not only $H$ but also $\Delta H_{\text {aw }}$ (enthalpy of phase change), represent the most inclusive data set for calculating temperature-adjusted $\mathrm{H}$ values for all 209 PCB congeners. However, the data by Bamford et al. (2002b, 2000) have generated considerable controversy. Recently, Goss et al. (2004) suggested that the inert gas stripping (IGS) technique used by many researchers and by Bamford et al. (2002b, 2000) may be subject to systematic artifacts especially for chemicals that experience appreciable adsorption to the water surface. Briefly, when the gas bubbles stripping the aqueous solution burst at the top of the water column, a fraction of the chemical adsorbed to the bubble surface is likely to be transferred to the gas-phase. Since the gasphase concentration will be biased high, this may result in apparent $H$ values that are higher than the actual values based on bulk air-water partitioning only. Baker et al. (2004) have challenged this explanation, and until recently there has been no agreement on the magnitude or on the presence of such an artifact (Lei et al., 2007). Recent experimental evidence obtained using n-alkanols as model compounds supported the hypothesized surface adsorption effect (Lei et al., 2007). Based on this experimental evidence and evaluation of IGS-determined $H$ values for various groups of semivolatile organic compounds by comparison with $H$ values either calculated from reliable vapor pressure and solubility data or derived from data compilations that achieve thermodynamic consistency through optimized adjustment of measured physical-chemical property data, Shunthirasingham et al. (2007) have concluded that a significant portion of $H$ values measured with IGS technique are biased high. Final adjustment procedure has been recently used to obtain internally consistent physicochemical properties for PCBs (Li et al., 2003; Schenker et al., 2005). Li et al. (2003) and Shunthirasingham et al. (2007) have pointed out that the $H$ values measured by Bamford et al. (2000) were consistently higher than the final adjusted values (FAVs) especially for larger PCBs. The calculation of temperature adjusted $H$ values for most of the congeners detected in the present study is possible using the data by Bamford et al. (2002b, 2000). However, based on the recent evaluations, this data was not used. Instead, the FAVs for PCBs derived by Schenker et al. (2005) that were recommended as the best currently available, were used in the present study. On the other hand, Shunthirasingham et al. (2007) have concluded that some studies using IGS technique appear to succeed in avoiding the adsorption artifact. The study by Cetin et al. (2006) was among those, and it was used to calculate the temperature adjusted $H$ values for OCPs in the present study.

The uncertainty of the calculated fugacity ratios and fluxes was assessed using a propagated error analysis. 
For each compound, measurement errors in $C_{\mathrm{a}}$ and $C_{\mathrm{w}}$, $H$ and $K_{\mathrm{a}}$ values were taken into account. The uncertainties of $C_{\mathrm{a}}$ and $C_{\mathrm{w}}$ were taken as $10 \%$ (Cetin and Odabasi, 2007; Bamford et al., 2002a). Uncertainty in saline water $H$ values for OCPs was $<12 \%$ (Cetin et al., 2006). Salting-out constants $\left(K_{\mathrm{s}}, \mathrm{L} \mathrm{mol}^{-1}\right)$ for PCBs that were calculated with the method by Ni and Yalkowsky (2003) using their octanol-water partition coefficients (Han et al., 2006) ranged between 0.341 (PCB-31) and 0.402 (PCB-180). $H^{*}$, the Henry's law constant in saline water was calculated using $\left[\log \left(H^{*} /\right.\right.$ $\left.H)=K_{\mathrm{s}} C_{\mathrm{s}}\right]$ where $C_{s}$ is the molar concentration of salt solution (measured as 0.51 and $0.62 \mathrm{M}$ for winter and summer samples, respectively). The studies reporting FAVs for PCBs did not report percent uncertainties associated with $H$ values, they reported uncertainty factors (Li et al., 2003; Schenker et al., 2005). The assignment of the uncertainty factors is somewhat subjective and there is no obvious and simple way to translate it into a measure of uncertainty that could be used in error propagation. Recently, Bruhn et al. (2003) assumed that FAVs for $H$ of PCBs derived by Li et al. (2003) have an uncertainty of $<30 \%$. The extent of adjustment that is required for thermodynamic consistency (i.e. the difference between literature derived values and FAVs) may also be interpreted as a measure of uncertainty, which is more easily quantifiable than the uncertainty factor ( $\mathrm{Li}$ et al., 2003; Wania, 2007). Based on the difference between literature derived values and FAVs reported by Schenker et al. (2005) the uncertainty in $H$ values for PCBs was estimated as $<25 \%$. Propagating the additional uncertainty for salting-out correction increases this value to $27 \%$. Unlike $k_{a}, k_{\mathrm{w}}$ is not linearly related to wind speed. Averaging wind speeds for long periods may underestimate $k_{\mathrm{w}}$ and $K_{\mathrm{a}}$. The relationship of Henry's law constant $(H)$ with temperature is also non-linear. To determine the nonlinear influences of meteorological parameters on $K_{\mathrm{a}}$, a sensitivity analysis was conducted using data averaged over 1 min intervals. The change in $K_{\mathrm{a}}$ ranged from $0.1 \%$ (PCB 180) to 4\% (PCB 31) for PCBs and they were nearly the same for OCPs relative to the estimates based on long-term averages of wind speed and temperature. The overall uncertainty of $K_{\mathrm{a}}$ value was assumed to be $40 \%$, based on the results of sensitivity analysis, previous evaluations, and the uncertainties in the air and water-side mass transfer coefficients $\left(k_{\mathrm{a}}\right.$ and $k_{\mathrm{w}}$ ), (Bamford et al., 2002a; Nelson et al., 1998; Hoff et al., 1996; Nightingale et al., 2000).

A propagation of the errors that are associated with the calculation indicated that the equilibrium is represented by an $f_{\mathrm{W}} / f_{\mathrm{A}}$ of $1.0 \pm 0.19$ (i.e., a range of

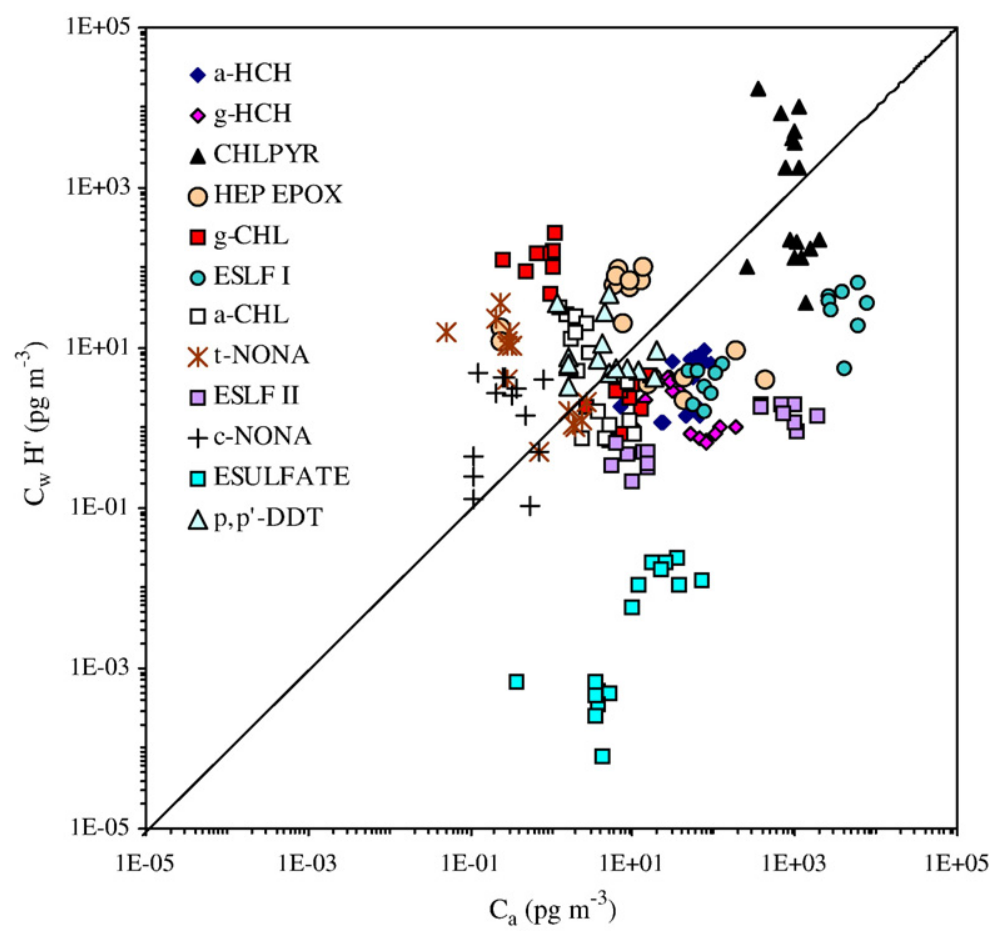

Fig. 2. Relationship between the OCP fugacities in water and air. The solid diagonal line represents a 1:1 relationship (equilibrium). 
0.81-1.19) for OCPs and a ratio of $1.0 \pm 0.31$ (i.e., a range of $0.69-1.31$ ) for PCBs. The fugacity ratios of all OCPs (except the ratios for trans-nonachlor, cisnonachlor, and $\mathrm{p}, \mathrm{p}^{\prime}$-DDT for five samples) fall outside this uncertainty range and we can be confident that for these compounds the water and ambient air are not in equilibrium (Fig. 2). Fugacity ratios for endosulfan I and II, endosulfan sulfate, $\alpha$ - and $\gamma$-HCHs were generally $<1.0$ indicating net deposition while the ratios for other congeners indicated deposition in winter and volatilization from the surface water in summer (Fig. 2). The fugacity ratios of most of the PCBs (except the ratios for $14 \%$ of all data) fall outside the uncertainty range indicating that for these compounds the water and ambient air are not in equilibrium (Fig. 3). Overall, the number of the samples indicating deposition and volatilization were similar. However, the number of the samples indicating PCB volatilization was doubled during the summer period.

Censoring can be used to decrease the weight of below detection values in the data set. Recent studies (Brankov et al., 1999; Singh and Nocerino, 2001) have indicated that for small size censored samples $(n \leq 10)$, the simple substitution of $\mathrm{LOD} / 2$ for censored data may be used and sometimes outperformed more complicated methods. In the present study, values below the detection limit were replaced by the half of the LOD. This was done only if there was a corresponding measured gas or dissolved-phase concentration. Censored below detection PCB values were 17 and $6 \%$ for dissolved and gas-phases, respectively. The substituted values with LOD/2 for OCPs were 6 and 7\% for dissolved and gas-phases, respectively. Net fluxes of PCBs and OCPs were calculated using Eqs. (1)-(6), and paired atmospheric gas and dissolved-phase water samples $(n=16)$ collected at the sampling site (Table 2 ).

The net gas-exchange PCB flux ranged from- -2.2 (volatilization, PCB-101) to-30.0 (volatilization, PCB31) $\mathrm{ng} \mathrm{m}^{-2}$ day $^{-1}$ (Table 2). Net PCB fluxes were mainly volatilization from water during the summer sampling period. Summer fluxes were generally higher than winter fluxes probably due to increased $H$ values with temperature (Table 2, Fig. 4). For OCPs, net flux ranged from -0.03 (cis-nonachlor) to 1568 (endosulfan I) $\mathrm{ng} \mathrm{m}^{-2}$ day $^{-1}$ (Table 2, Fig. 5). In winter, OCPs were generally deposited to surface water, while in summer they have more volatilization tendency. The depositional trends of endosulfan I and II, and their degradation product, endosulfan sulfate indicated that surface waters may be an important sink for these

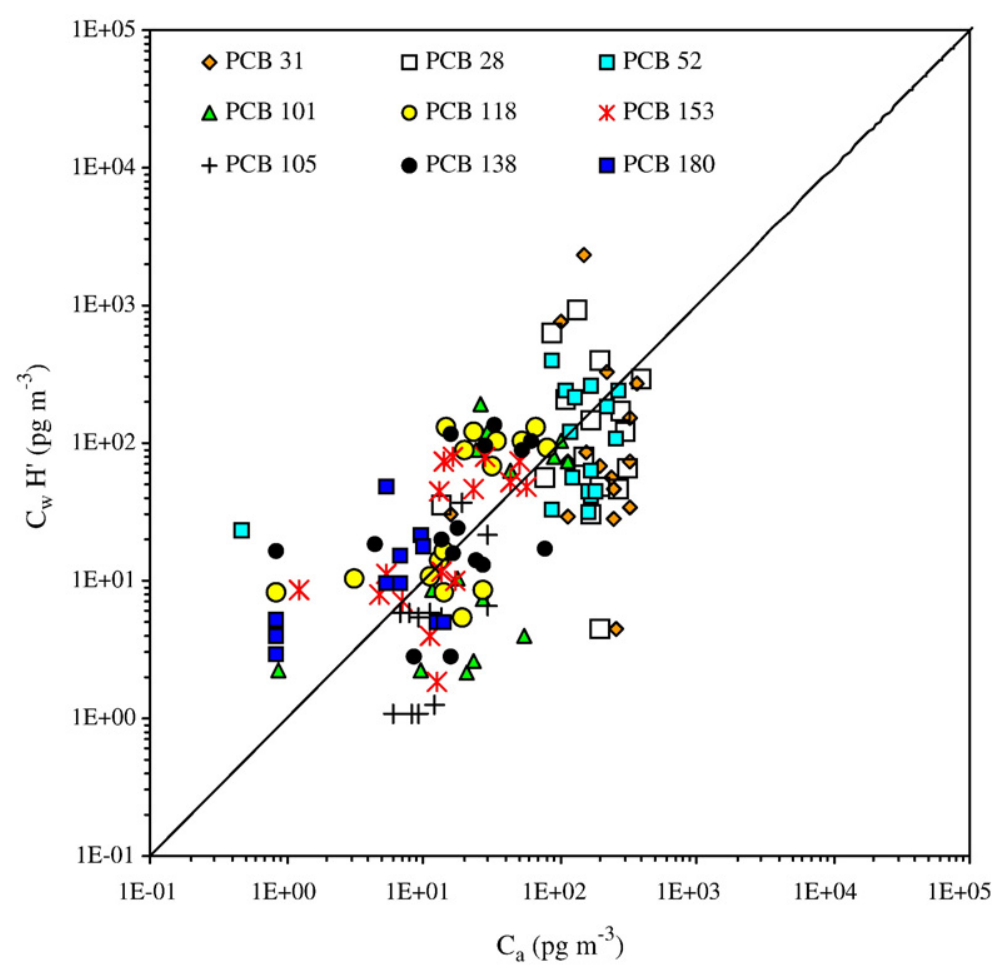

Fig. 3. Relationship between the PCB fugacities in water and air. The solid diagonal line represents a 1:1 relationship (equilibrium). 
Table 2

Calculated air-water exchange fluxes ${ }^{\mathrm{a}}\left(\mathrm{ng} \mathrm{m}^{-2}\right.$ day $\left.^{-1}\right)$

\begin{tabular}{|c|c|c|c|c|c|c|}
\hline & \multicolumn{3}{|l|}{ Winter } & \multicolumn{3}{|c|}{ Summer } \\
\hline & Min. & Max. & Average \pm SD & Min. & Max. & Average \pm SD \\
\hline \multicolumn{7}{|l|}{$P C B s$} \\
\hline PCB 31 & -1.3 & 25.4 & $11.5 \pm 8.4$ & 3.5 & -30.0 & $-6.3 \pm 14.0$ \\
\hline PCB 28 & -2.0 & 21.0 & $8.6 \pm 8.0$ & 2.8 & -22.1 & $-5.5 \pm 9.9$ \\
\hline PCB 52 & -2.1 & 11.4 & $6.3 \pm 4.4$ & 2.3 & -12.7 & $-3.0 \pm 5.7$ \\
\hline PCB 101 & -0.2 & 5.6 & $1.6 \pm 1.9$ & 0.8 & -4.6 & $-1.6 \pm 2.0$ \\
\hline PCB 118 & -1.4 & 3.0 & $0.7 \pm 2.1$ & -1.9 & -8.4 & $-3.6 \pm 2.3$ \\
\hline РCB 153 & -1.0 & 1.2 & $0.01 \pm 0.9$ & -0.7 & -3.2 & $-1.3 \pm 1.0$ \\
\hline PCB 105 & 0.7 & 1.8 & $1.2 \pm 0.5$ & 0.8 & -0.9 & $0.3 \pm 0.6$ \\
\hline PCB 138 & 1.2 & -1.6 & $-0.1 \pm 1.1$ & 0.8 & -2.3 & $-0.8 \pm 1.0$ \\
\hline PCB 180 & -0.4 & -0.7 & $-0.6 \pm 0.1$ & 0.6 & -1.8 & $-0.5 \pm 0.8$ \\
\hline$\Sigma_{9} \mathrm{PCBs}$ & -10.2 & 61.9 & $28.3 \pm 24.3$ & 11.3 & -74.5 & $-17.8 \pm 29.7$ \\
\hline \multicolumn{7}{|l|}{$O C P S$} \\
\hline$\alpha-\mathrm{HCH}$ & 1.9 & 21.8 & $12.8 \pm 7.2$ & 5.9 & 24.8 & $16.4 \pm 7.0$ \\
\hline$\gamma-\mathrm{HCH}$ & 3.4 & 64.9 & $27.5 \pm 18.4$ & 4.0 & 10.8 & $7.4 \pm 2.7$ \\
\hline CHLPYR & 25.9 & 293 & $142 \pm 85.8$ & -23.3 & -463 & $-202 \pm 154$ \\
\hline HEP EPOX & -1.9 & 41.9 & $11.0 \pm 17.6$ & -2.0 & -12.8 & $-6.0 \pm 3.4$ \\
\hline$\gamma$-CHL & 0.1 & 1.2 & $0.5 \pm 0.4$ & -0.7 & -5.1 & $-2.0 \pm 1.6$ \\
\hline ESLF I & 9.6 & 29.7 & $16.5 \pm 6.6$ & 291.1 & 1568 & $639 \pm 423$ \\
\hline$\alpha-\mathrm{CHL}$ & 0.2 & 1.1 & $0.6 \pm 0.3$ & -0.1 & -1.5 & $-0.7 \pm 0.6$ \\
\hline t-NONA & 0.04 & 0.2 & $0.05 \pm 0.1$ & -0.1 & -1.0 & $-0.4 \pm 0.3$ \\
\hline ESLF II & 1.7 & 5.2 & $3.2 \pm 1.3$ & 79.5 & 666 & $271 \pm 193$ \\
\hline c-NONA & -0.03 & 0.1 & $0.02 \pm 0.1$ & -0.2 & -0.8 & $-0.4 \pm 0.2$ \\
\hline ESULFATE & 0.1 & 1.8 & $1.1 \pm 0.5$ & 3.0 & 27.3 & $9.6 \pm 8.0$ \\
\hline $\mathrm{p}, \mathrm{p}^{\prime}-\mathrm{DDT}$ & -0.4 & 2.2 & $0.4 \pm 1.5$ & -0.4 & -4.1 & $-2.1 \pm 2.0$ \\
\hline
\end{tabular}

${ }^{\text {a }}$ Negative values indicate volatilization from water.

currently used pesticides. However, the fluxes of chlorpyrifos, another currently used OCP, were depositional in winter while it was volatilized in summer.
Dissolved-phase chlorpyrifos concentrations in summer were higher than those measured in winter. Higher summer temperatures also increased the $H$ values $(\sim 6.5$

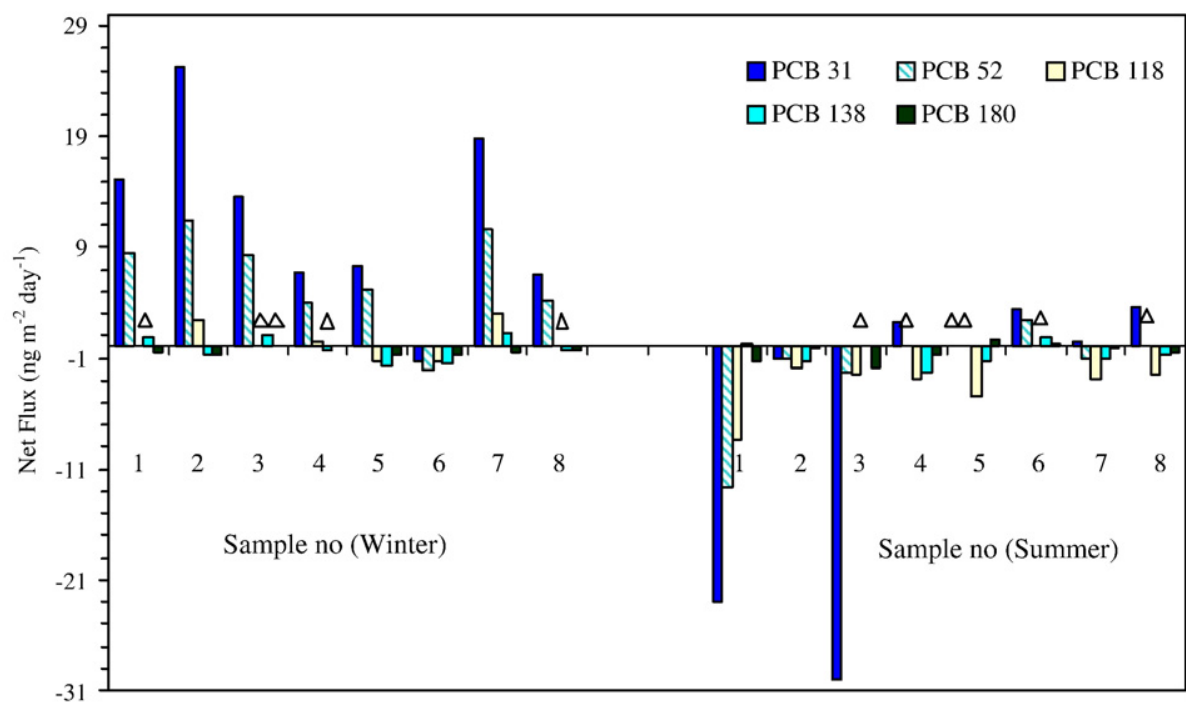

Fig. 4. Net gas exchange fluxes of selected PCBs $\left(n g \mathrm{~m}^{-2}\right.$ day ${ }^{-1}$ ) for summer and winter 2005 sampling periods. $(\Delta)$ not calculated (near equilibrium). Negative values indicate volatilization from water. 

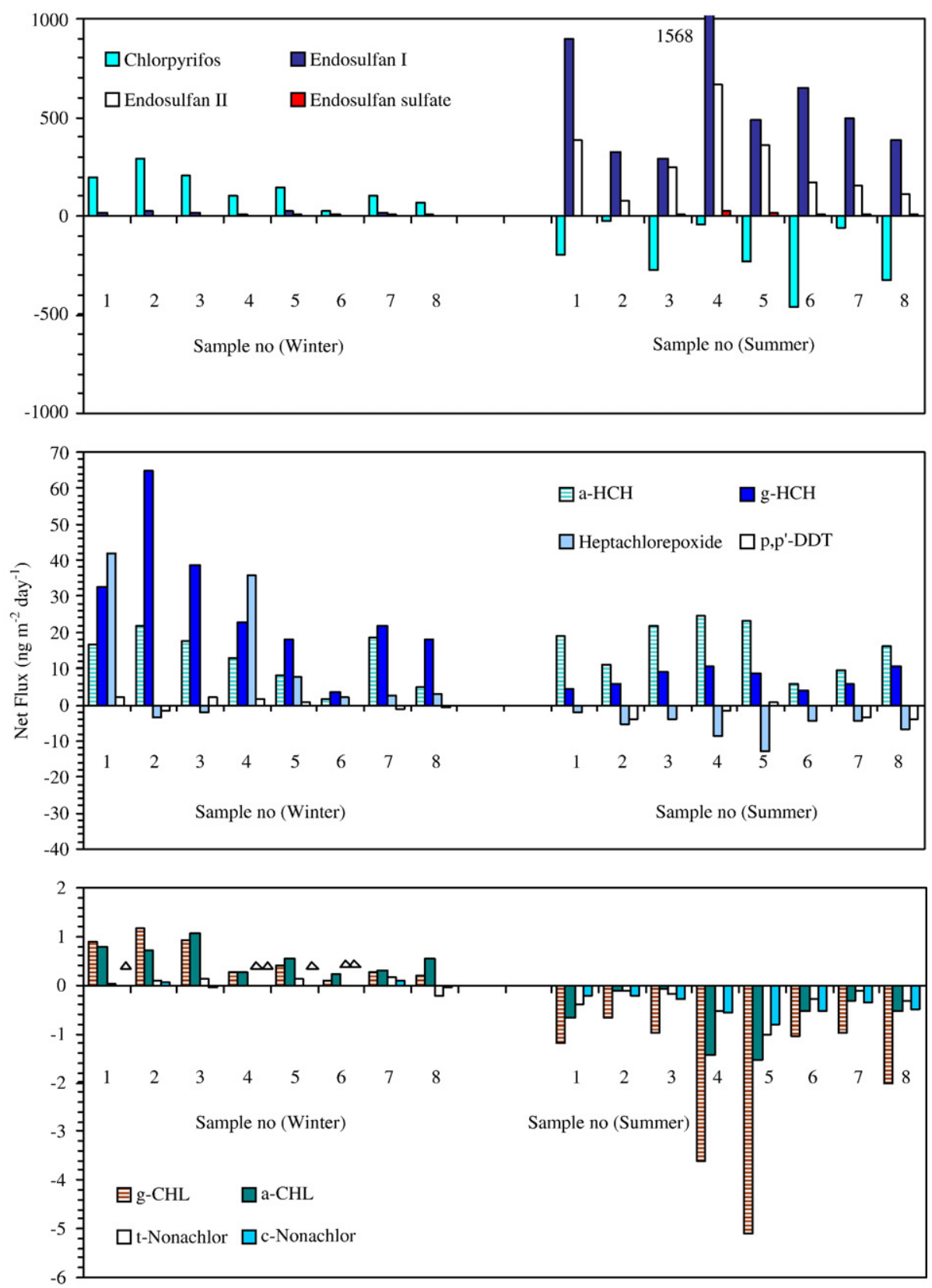

Fig. 5. Net gas exchange fluxes of individual OCPs $\left(\mathrm{ng} \mathrm{m}^{-2}\right.$ day ${ }^{-1}$ ) for summer and winter 2005 sampling periods. $(\Delta)$ not calculated (near equilibrium). Negative values indicate volatilization from water.

times) favoring the shift in the direction of air-water exchange for this OCP.

Hornbuckle et al. (1994) have reported that the $\sum$ PCB fluxes ranged between -110 and $40 \mathrm{ng} \mathrm{m}^{-2}$ day $^{-1}$ in Lake Superior. The fluxes of $\sum$ PCBs in spring were depositional while they were volatilized in summer. In another study conducted in Lake Michigan in September 1991, all PCB fluxes were from water to air and they ranged from -24 to $-220 \mathrm{ng} \mathrm{m}^{-2}$ day $^{-1}$ (Hornbuckle et al., 1995). Totten et al. (2001) have also found net volatilization for PCBs in the New York-New Jersey Harbor Estuary in July 1998 and the net flux ranged from -310 to $-2700 \mathrm{ng} \mathrm{m}^{-2}$ day $^{-1}$. Bamford et al. $(2002 a, b)$ have reported that the volatilization fluxes of PCBs were between -5 and $-2120 \mathrm{ng} \mathrm{m}^{-2}$ day $^{-1}$ across Baltimore Harbor and the Northern Chesapeake Bay. Net 
fluxes for PCBs obtained in the present study were within the ranges of previously reported values. $\alpha$-and $\gamma$-HCHs were found to be deposited in the Kattegat Sea from December 1998 to November 1999 with net fluxes of 4.2 and $6.6 \mathrm{ng} \mathrm{m}^{-2}$ day $^{-1}$ (Sundqvist et al., 2004). The reported volatilization fluxes for chlorpyrifos ranged between 0.16-42 $\mathrm{ng} \mathrm{m}^{-2}$ day $^{-1}$ in Chesapeake Bay (McConnell et al., 1997). These values were generally lower than those observed in the present study.

The estimated uncertainty in the PCB fluxes calculated by error propagation ranged between 48 (PCB-31)-53\% (PCB-138) for individual congeners (overall, $\pm 50 \%$ ). However, relatively higher values for PCB-153 (up to $78 \%$ ) were calculated for some sampling days. The fluxes for these samples were comparably lower than the other days and their high uncertainty was probably due to the proximity to equilibrium. The estimated uncertainty in the OCP fluxes ranged between 41 (endosulfan I)$48 \%$ ( $\mathrm{p}, \mathrm{p}^{\prime}$-DDT) (overall, $\pm 44 \%$ ). For some sampling days, the calculated uncertainty values for trans-nonachlor were relatively higher (up to $84 \%$ ).

Wind speed and water temperature are the key factors controlling air-water exchange. The wind speeds and water temperatures during the sampling programs were not significantly different than the seasonal averages (Cetin and Odabasi, 2007). Assuming that the measured atmospheric and aqueous concentrations are also representative for the winter and summer periods, it could be concluded that the reported air-water exchange fluxes are representative of the area studied and the sampling seasons.

PCBs and OCPs in the water column partition into the dissolved, particle, and the dissolved organic carbon (DOC) phases (Rowe et al., 2007). The sampling procedure used in the present study cannot distinguish the truly dissolved pollutant concentration $\left(C_{\mathrm{w}}\right)$ from the apparent dissolved concentration $\left(C_{\mathrm{w}, \mathrm{a}}\right)$. The following equation was recently used to estimate the truly dissolved concentration (Rowe et al., 2007):

$C_{w}=C_{w, a} /\left(1+K_{\mathrm{DOC}} \mathrm{DOC}\right)$

where $K_{\mathrm{DOC}}$ is the partitioning coefficient between the truly dissolved compound and dissolved organic carbon $\left(\mathrm{L} \mathrm{kg}^{-1}\right), D O C$ is the concentration of the dissolved organic carbon $\left(\mathrm{kg} \mathrm{L}^{-1}\right)$. Burkhard (2000) have developed a predictive relationship for $K_{\mathrm{DOC}}$ assuming that it is a function of octanol-water partition coefficient $\left(K_{\mathrm{OW}}\right)$ :

$K_{\mathrm{DOC}}=m K_{\mathrm{OW}}$

An evaluation of literature data suggested that the $m$ is about 0.08 for most hydrophobic organic contami- nants. This predictive relationship is highly uncertain with $95 \%$ confidence limits of a factor of 20 in either direction (Burkhard, 2000). DOC concentrations were not measured in the present study but recently an average value of $1.1 \times 10^{-6} \mathrm{~kg} \mathrm{~L}^{-1}$ was reported for the inner Bay (Kucuksezgin et al., 2005). Even though sample specific values were not available, $C_{\mathrm{w}} / C_{\mathrm{w}, \mathrm{a}}$ ratios for PCBs and OCPs were approximated using their $K_{\mathrm{OW}}$ values and the recently reported average DOC concentration (Eqs. (7) and (8)). $C_{\mathrm{w}} / C_{\mathrm{w}, \mathrm{a}}$ ratios ranged between 0.82 (95\% confidence interval, 0.18 $0.99)-1.00$ (95\% confidence interval, $0.99-1.00)$ and 0.20 (95\% confidence interval, 0.01-0.83)-0.93 (95\% confidence interval, 0.41-1.00) for OCPs and PCBs, respectively. These results suggested that for most of the OCPs the truly dissolved pollutant concentration is close to the apparent dissolved concentration while for some PCBs (PCB-118, 153, 105, 138 and 180) the truly dissolved concentration may have been overestimated. Overestimation of truly dissolved concentrations may result in an overestimation in volatilization fluxes (Eq. (3)). However, it is not possible to accurately determine the $C_{\mathrm{w}} / C_{\mathrm{w}, \mathrm{a}}$ ratios due to the high uncertainty associated with the calculation of $K_{\mathrm{DOC}}$, especially for the compounds with $\log K_{\mathrm{OW}}>6.0$. Burkhard (2000) have suggested that characterizing DOC by just measuring total dissolved organic carbon does not adequately describe this phase. It was also suggested that the ratio of aromatic to aliphatic content for humic acids might be a very useful characterization tool.

The importance of deposition as an input or volatilization as a removal process relative to advection of PCBs and OCPs out of the water column of Izmir Bay was further assessed by comparing the residence times of dissolved-phase PCBs and OCPs in the water column reflecting only air-water fluxes versus the residence time of water in the inner Bay. The hydraulic residence time for the inner Bay water is 85 days (Sayin, 2003). The residence time of chemicals in the water column $\left(\tau_{\mathrm{AW}}\right)$, considering only dissolved-phase concentrations that are subject to air-water exchange, is given by (Gigliotti et al., 2002):

$\tau_{A W}=$ Inventory $/$ Net flux $=\left(C_{\text {dissolved }} h_{w}\right) / F_{g}$

The residence times of PCBs and OCPs were calculated using the estimated net fluxes $\left(F_{\mathrm{g}}, \mathrm{ng} \mathrm{\textrm {m } ^ { - 2 }}\right.$ day $\left.^{-1}\right)$, measured dissolved-phase concentrations $\left(C_{\text {dissolved, }}\right.$ $\mathrm{ng} \mathrm{m}^{-3}$ ), and the average water depth for the inner Bay $\left(h_{\mathrm{w}}, 10 \mathrm{~m}\right) . \tau_{\mathrm{AW}}$ values of PCBs ranged from 7 to 63 days for winter and 26 to 62 days for summer periods. For OCPs, they ranged from 4 to 209 days and 1 to 109 days 
for winter and summer periods, respectively. These results suggest that PCB and OCP gas-exchange in the Bay is at least as or a more important mechanism than advection.

\subsection{Dry particle and wet deposition}

In addition to gas-exchange, other atmospheric inputs into the Bay (i.e., dry particle and wet deposition) contribute to the water column total PCB and OCP inventory. Dry deposition fluxes were calculated and used along with the recently measured wet deposition fluxes (Odabasi, in press) to estimate relative importance of different atmospheric mechanisms (i.e., dry deposition, wet deposition, gas absorption, and volatilization). The dry deposition fluxes of POPs associated with particles can be estimated using an overall dry deposition velocity $\left(V_{p}\right)$ and particle-phase air concentrations $\left(C_{p}\right)$ :

$F_{p}=V_{p} C_{p}$

Reported overall particle dry deposition velocities $\left(V_{p}\right)$ for various POPs range between 0.4 and $6.7 \mathrm{~cm} \mathrm{~s}^{-1}$ (Tasdemir et al., 2004; Odabasi et al., 1999). Recently, dry deposition velocities of PCBs and OCPs were determined using particle dry deposition and ambient air samples collected at two sites (urban and suburban) within a few kilometers of the sampling site of the present study. $V_{p}$ values ranged between 5.2 (PCB-153) $-7.7 \mathrm{~cm} \mathrm{~s}^{-1}$ (PCB-49) and between 1.6 (endosulfan sulfate) $-8.0 \mathrm{~cm} \mathrm{~s}^{-1}$ (heptachlor epoxide) for PCBs and OCPs, respectively (Odabasi, in press). The factor difference of $V_{p}$ values at urban and suburban sites ranged between 0.4-2.7 (average $\pm \mathrm{SD}, 1.3 \pm 0.6$ ). On the basis of these observations, it was estimated that the uncertainty in $V_{p}$ values used in calculation of particlephase fluxes in the present study was a factor of 2. Dry deposition fluxes $\left(F_{p}\right)$ for PCBs and OCPs in Guzelyali Port were estimated using these deposition velocities and measured particle-phase air concentrations.

Annual gaseous absorption and volatilization fluxes were calculated using Eqs. (2) and (3) and were used along with the estimated dry deposition fluxes and wet deposition fluxes measured recently at a suburban site in Izmir (Odabasi, in press) to determine the relative contributions of different mechanisms to the pollutant inventory of the Bay water column (Table 3). This assessment is based on the mechanisms included in the present study (particle dry deposition, wet deposition, gas absorption, and volatilization). Additional mechanisms (river/stream outflows, terrestrial run-off, domestic and industrial wastewater discharges) could also
Table 3

Annual fluxes of OCPs and $\Sigma_{9}$ PCBs $\left(\mathrm{ng} \mathrm{m}^{-2}\right.$ year $^{-1}$ )

\begin{tabular}{lcrrr}
\hline & \multicolumn{1}{l}{$\begin{array}{l}\text { Dry } \\
\text { deposition }\end{array}$} & \multicolumn{1}{l}{$\begin{array}{l}\text { Wet } \\
\text { deposition }\end{array}$} & \multicolumn{1}{l}{$\begin{array}{l}\text { Gas } \\
\text { absorption }\end{array}$} & Volatilization \\
\hline$\alpha$-HCH & 2013 & 351 & 5775 & 452 \\
$\gamma$-HCH & 5464 & 408 & 6609 & 246 \\
CHLPYR & 141,711 & 18,885 & 37,134 & 48,210 \\
HEP EPOX & 7492 & 2998 & 2424 & 1509 \\
$\gamma$-CHL & 481 & 463 & 137 & 397 \\
ESLF I & 10,540 & 820 & 120,720 & 1048 \\
$\alpha$-CHL & 461 & 361 & 149 & 165 \\
t-NONA & 285 & 335 & 39 & 100 \\
ESLF II & 28,801 & 632 & 50,211 & 106 \\
c-NONA & 224 & 89 & 20 & 98 \\
ESULFATE & 5787 & 348 & 1958 & 1 \\
p,p'-DDT & 3544 & 477 & 456 & 672 \\
$\Sigma_{9}$ PCBs & 58,850 & 4809 & 11,558 & 9453 \\
\hline
\end{tabular}

significantly contribute to the Bay water column pollutant inventory. However, it is not possible to estimate their magnitude and relative importance. All studied mechanisms were comparable for $\Sigma_{9} \mathrm{PCBs}$ however their input was dominated by dry deposition. Generally, all mechanisms contributed significantly to the water column OCP inventory. However, gas absorption for endosulfan I and II and dry deposition for endosulfan sulfate were dominating. Contributions of all mechanisms were important for chlorpyrifos, the other currently used OCP included in this study. The contribution of wet deposition was significant especially for chlordanes, nonachlors and heptachlor epoxide. Volatilization fluxes were generally much lower than the sum of input fluxes (dry and wet deposition, gas absorption) for all compounds suggesting a net accumulation in the water column (Table 3 ).

\section{Acknowledgements}

This study was supported in part by the scientific research fund of Dokuz Eylul University (Project No: 03.KB.FEN.101), by the Scientific and Technical Research Council of Turkey (TUBITAK) (Project no. ICTAG-C033), and the scientific research fund of the Izmir Institute of Technology (Project no. IYTE-20). We would like to thank Remzi Seyfioglu, Hulusi Demircioglu, and Hasan Altiok (Dokuz Eylul University) for their help during field sampling.

\section{References}

Bamford, H.A., Ko, F.C., Baker, J.E., 2002a. Seasonal and annual airwater exchange of polychlorinated biphenyls across Baltimore Harbor and the Northern Chesapeake Bay. Environ. Sci. Technol. $36,4245-4252$. 
Bamford, H.A., Poster, D.L., Huie, R.E., Baker, J.E., 2002b. Using extrathermodynamic relationships to model the temperature dependence of Henry's law constants of 209 PCB congeners. Environ. Sci. Technol. 36, 4395-4402.

Bamford, H.A., Poster, D.L., Baker, J.E., 2000. Henry's law constants of polychlorinated biphenyl congeners and their variation with temperature. J. Chem. Eng. Data 45, 1069-1074.

Baker, J.E., Totten, L.A., Gigliotti, C.L., Offenberg, J.H., Eisenreich, S.J., Bamford, H.A., Huie, R.E., Poster, D.L., 2004. Response to comment on "Reevaluation of air-water exchange fluxes of PCBs in green bay and southern Lake Michigan". Environ. Sci. Technol. 38, 1629-1632.

Brankov, E., Rao, S.T., Porter, P.S., 1999. Identifying pollution source regions using multiply censured data. Environ. Sci. Technol. 33, 2273-2277.

Bruhn, R., Lakaschus, S., McLachlan, M.S., 2003. Air/sea gas exchange of PCBs in the southern Baltic Sea. Atmos. Environ. 37, 3445-3454.

Brunciak, P.A., Dachs, J., Franz, T.P., Gigliotti, C.L., Nelson, E.D., Turpin, B.J., Eisenreich, S.J., 2001. Polychlorinated biphenyls and particulate organic/elemental carbon in the atmospheres of Chesapeake Bay, USA. Atmos. Environ. 35, 5663-5677.

Buehler, S.S., Basu, I., Hites, R.A., 2001. A comparison of PAH, PCB, and pesticide concentrations in air at two rural sites on Lake Superior. Environ. Sci. Technol. 35, 2417-2422.

Burkhard, L.P., 2000. Estimating dissolved organic carbon partition coefficients for nonionic organic chemicals. Environ. Sci. Technol. 34, 4663-4668.

Cetin, B., Odabasi, M., 2007. Air-Water Exchange and Dry Deposition of Polybrominated Diphenyl Ethers at a Coastal Site in Izmir Bay, Turkey. Environ. Sci. Technol. 41, 785-791.

Cetin, B., Ozer, S., Sofuoglu, A., Odabasi, M., 2006. Determination of Henry's law constants of organochlorine pesticides in deionized and saline water as a function of temperature. Atmos. Environ. 40, 4538-4546.

Gigliotti, C.L., Brunciak, P.A., Dachs, J., Glenn, T.R., Nelson, E.D., Totten, L.A., Eisenreich, S.J., 2002. Air-water exchange of polycyclic aromatic hydrocarbons in the New York-New Jersey, USA, Harbor Estuary. Environ. Toxicol. Chem. 21, 235-244.

Goss, K.U., Wania, F., McLachlan, M.S., Mackay, D., Schwarzenbach, R.P., 2004. Comment on "Reevaluation of air-water exchange fluxes of PCBs in green bay and southern Lake Michigan". Environ. Sci. Technol. 38, 1626-1628.

Green, M.L., Depinto, J.V., Sweet, C., Hornbuckle, K.C., 2000. Regional spatial and temporal interpretation of Lake Michigan: mass balance data. Environ. Sci. Technol. 34, 1833-1841.

Halsall, C.J., Gevao, B., Howsam, M., Lee, R.G.M., Ockenden, W.A., Jones, K.C., 1999. Temperature dependence of PCBs in the UK atmosphere. Atmos. Environ. 33, 541-552.

Han, X.Y., Wang, Z.Y., Zhai, Z.C., Wang, L.S., 2006. Estimation of n-octanol/water partition coefficients $\left(\mathrm{K}_{\mathrm{ow}}\right)$ of all PCB congeners by ab initio and a $\mathrm{Cl}$ substitution position method. QSAR Comb. Sci. 25, 333-341.

Hoff, R.M., Strachan, W.M.J., Sweet, C.W., Chan, C.H., Shackleton, M., Bidleman, T.F., Brice, K.A., Burniston, D.A., Cussion, S., Gatz, D.F., Harlin, K., Schroede, W.H., 1996. Atmospheric deposition of toxic chemicals to the Great Lakes: A review of data through 1994. Atmos. Environ. 30, 3505-3527.

Hornbuckle, K.C., Jeremlason, J.D., Sweet, C.W., Eisenreich, S.J., 1994. Seasonal variations in air-water exchange of polychlorinated biphenyls in Lake Superior. Environ. Sci. Technol. 28, $1491-1501$
Hornbuckle, K.C., Sweet, C.W., Pearson, R.F., Swackhamer, D.L., Eisenreich, S.J., 1995. Assessing annual water-air fluxes of polychlorinated biphenyls in Lake Michigan. Environ. Sci. Technol. 29, 869-877.

Jaward, F.M., Barber, J.L., Booij, K., Dachs, J., Lohmann, R., Jones, K.C., 2004. Evidence for dynamic air-water coupling and cycling of persistent organic pollutants over the open Atlantic Ocean. Environ. Sci. Technol. 38, 2617-2625.

Kontas, A., Kucuksezgin, F., Altay, O., Uluturhan, E., 2004. Monitoring of eutrophication and nutrient limitation in the Izmir Bay (Turkey) before and after Wastewater Treatment Plant. Environ. Int. 29, 1057-1062.

Kucuksezgin, F., Kontas, A., Altay, O., Uluturhan, E., 2005. Elemental composition of particulate matter and nutrient dynamics in the Izmir Bay (Eastern Aegean). J. Mar. Syst. 56, 67-84.

Kucuksezgin, F., Kontas, A., Altay, O., Uluturhan, E., Darilmaz, E., 2006. Assessment of marine pollution in Izmir Bay: Nutrient, heavy metal and total hydrocarbon concentrations. Environ. Int. 32, 41-51.

Lee, R.G.M., Burnett, V., Harner, T., Jones, K.C., 2000. Short term temperature dependent air-surface exchange and atmospheric concentrations of polychlorinated naphthalenes and organochlorine pesticides. Environ. Sci. Technol. 34, 393-398.

Lee, W.-J., Sue, J.L.L., Chen, Y.-Y., Wang, Y.-F., Sheu, H.-L., Su, C.-C., Fan, Y.-C., 1996. Polychlorinated biphenyls in the ambient air petroleum refinery, urban and rural areas. Atmos. Environ. 30, 2371-2378.

Lei, Y.D., Shunthirasingham, C., Wania, F., 2007. Comparison of headspace and gas-stripping techniques for measuring the airwater partitioning of normal alkanols (C4 to $\mathrm{C} 10)$ : Effect of temperature, chain length, and adsorption to the water surface. J. Chem. Eng. Data 52, 168-179.

Li, N.Q., Wania, F., Lei, Y.D., Daly, G.L., 2003. A comprehensive and critical compilation, evaluation, and selection of physical-chemical property data for selected polychlorinated biphenyls. J. Phys. Chem. Ref. Data 32, 1545-1590.

Luo, X.J., Mai, B.X., Yang, Q.S., Fu, J.M., Sheng, G.Y., Wang, Z.S., 2004. Polycyclic aromatic hydrocarbons (PAHs) and organochlorine pesticides in water columns from the Pearl River and the Macao harbor in the Pearl River Delta in South China. Mar. Pollut. Bull. $48,1102-1115$.

McConnell, L.L., Nelson, E., Rice, C.P., Baker, J.E., Johnson, W.E., Harman, J.E., Bialek, K., 1997. Chlorpyrifos in the air and surface water of Chesapeake Bay: predictions of atmospheric deposition fluxes. Environ. Sci. Technol. 31, 1390-1398.

Miller, S.M., Green, M.L., Depinto, J.V., Hornbuckle, K.C., 2001 Results from the Lake Michigan mass balance study: concentrations and fluxes of atmopsheric polychlorinated bipheyls and transnonachlor. Environ. Sci. Technol. 35, 278-285.

Moschandreas, D.J., Kim, Y., Karuchit, S., Ari, H., Lebowitz, M.D., O'Rourke, M.K., Gordon, S., Robertson, G., 2001. In-residence, multiple route exposures to chlorpyrifos and diazinon estimated by indirect method models. Atmos. Environ. 35, 2201-2213.

Murayama, H., Takase, Y., Mitobe, H., Mukai, H., Ohzeki, T., Shimizu, K., Kitayama, Y., 2003. Seasonal change of persistent organic pollutant concentrations in air at Niigata Area, Japan. Chemosphere 52, 683-694.

Nelson, E.D., McConnell, L.L., Baker, J.E., 1998. Diffusive exchange of gaseous polycyclic aromatic hydrocarbons and polychlorinated biphenyls across the air-water interface of the Chesapeake Bay. Environ. Sci. Technol. 32, 912-919.

Ni, N., Yalkowsky, H., 2003. Prediction of Setschenow constants. Int. J. Pharm. 254, 167-172. 
Nightingale, P.D., Liss, P., Schlosser, P., 2000. Measurements of airsea transfer during an open ocean algal bloom. Geophys. Res. Lett. 27, 2117-2120.

Odabasi, M., in press. Unpublished results. Department of Environmental Engineering, Dokuz Eylul University, Izmir, Turkey.

Odabasi, M., Sofuoglu, A., Vardar, N., Tasdemir, Y., Holsen, T.M., 1999. Measurement of dry deposition and air-water exchange of polycyclic aromatic hydrocarbons with the water surface sampler. Environ. Sci. Technol. 33, 426-434.

Rowe, A.A., Totten, L.A., Xie, M., Fikslin, T.J., Eisenreich, S.J., 2007. Air-water exchange of polychlorinated biphenyls in the Delaware River. Environ. Sci. Technol. 41, 1152-1158.

Sayin, E., 2003. Physical features of the Izmir Bay. Cont. Shelf Res. 23, 957-970.

Schenker, U., MacLeod, M., Scheringer, M., Hungerbuhler, K., 2005. Improving data quality for environmental fate models: a least-squares adjustment procedure for harmonizing physicochemical properties of organic compounds. Environ. Sci. Technol. 39, 8434-8441.

Schwarzenbach, R.P., Gschwend, P.M., Imboden, D.M., 2003. Environmental Organic Chemistry (Second Edition). Wiley-Interscience, New York.

Shunthirasingham, C., Lei, Y.D., Wania, F., 2007. Evidence of bias in air-water Henry's law constants for semivolatile organic compounds measured by inert gas stripping. Environ. Sci. Technol. 41, 3807-3814.

Simcik, M.F., Zhang, H., Eisenreich, S.J., Franz, T.P., 1997. Urban contamination of the Chicago/coastal Lake Michigan atmosphere by PCBs and PAHs during AEOLOS. Environ. Sci. Technol. 31, 2141-2147.
Singh, A., Nocerino, J., 2001. Robust estimation of mean and variance using environmental data sets with below detection limit observations. Available from: United States Environmental Protection Agency Web site: http://www.epa.gov/nerlesd1/tsc/images/robustestim.pdf.

Sofuoglu, A., Cetin, E., Bozacioglu, S.S., Sener, G.D., Odabasi, M., 2004. Short-term variation in ambient concentrations and gas/ particle partitioning of organochlorine pesticides in Izmir, Turkey. Atmos. Environ. 38, 4483-4493.

Sundqvist, K.L., Wingfors, H., Brorstöm-Lunden, E., Wiberg, K., 2004. Air-sea gas exchange of HCHs and PCBs and enantiomers of $\alpha-\mathrm{HCH}$ in the Kattegat Sea region. Environ. Pollut. 128, 73-83.

Sweet, C.W., Murphy, T.J., Bannach, J.H., Kelsey, C.A., Hong, J., 1993. Atmospheric deposition of PCBs into Green Bay. J. Great Lakes Res. 19, 109-128.

Tasdemir, Y., Odabasi, M., Holsen, T.M., 2005. Measurement of the vapor phase deposition of polychlorinated bipheyls (PCBs) using a water surface sampler. Atmos. Environ. 39, 885-897.

Tasdemir, Y., Odabasi, M., Vardar, N., Sofuoglu, A., Murphy, T.J., Holsen, T.M., 2004. Dry deposition fluxes and velocities of polychlorinated biphenyls (PCBs) associated with particles. Atmos. Environ. 38, 2447-2456.

Totten, L.A., Brunciak, P.A., Gigliotti, C.L., Dachs, J., Glenn, T.R., Nelson, E.D., Eisenreich, S.J., 2001. Dynamic air-water exchange of polychlorinated biphenyls in the New York- New Jersey Harbor Estuary. Environ. Sci. Technol. 35, 3834-3840.

Wania, F., 2007. Department of Physical and Environmental Sciences, University of Toronto at Scarborough, Toronto, Ontario, Canada. Personal communication. 